\title{
Low Level of Physical Activity in Two Roma Subgroups Compared to Non-Roma Population in Niraj Valley, Transylvania
}

\author{
Monica I. Szabó1,2, Anita Balázs², Beáta Máté2, Piroska Kelemen,3 \\ 1 Department of Internal Medicine, University of Medicine, Pharmacy, Science and Technology, Târgu Mureș, Romania \\ 2 Clinic of Diabetology, Emergency County Clinic, Târgu Mureș, Romania \\ ${ }^{3}$ Clinic of Internal Medicine, Emergency County Clinic, Târgu Mureș, Romania
}

\section{CORRESPONDENCE}

\section{Mónika I. Mária Szabó}

Str. Gheorghe Marinescu nr. 38

540139 Târgu Mureș, Romania

Tel: +40 722338 141, +40 265268595

E-mail: szabo.monika@umftgm.ro,

sztamo@gmail.com

\section{ARTICLE HISTORY}

Received: October 4, 2018

Accepted: January 18, 2019
Anita Balázs • Str. Gheorghe Marinescu nr. 50, 540136 Târgu Mureș, Romania. Tel: +40 746959 886, E-mail: gerebanita@yahoo.com

Beáta Máté • Str. Gheorghe Marinescu nr. 50, 540136 Târgu Mureș, Romania. Tel: +40 743045 282, E-mail: juhos_beata@yahoo.com

Piroska Kelemen • Str. Gheorghe Marinescu nr. 50 , 540136 Târgu Mureș, Romania. Tel: +40 740148 589, E-mail: piroska_kelemen@yahoo.com

\begin{abstract}
Objective: A low level of physical activity is a cardiovascular risk factor. Physical activity patterns may differ among different ethnic groups. Aim of the study: Our aim was to evaluate the physical activity patterns of two different Roma populations compared to non-Roma. Material and Methods: The study population included 231 Gabor Roma, 111 Băieși Roma, and 183 nonRoma. A 70-item questionnaire was administered, including also the short form of the International Physical Activity Questionnaire, evaluating daily physical activity in minutes and physical activity categories such as walking, gardening, household activity, and sports. Anthropometric parameters (weight, height, waist and hip circumference) were measured. Results: The level of physical activity was the lowest among Gabor Roma and was lower in both Roma groups than in non-Roma (Gabor Roma $118.6 \pm 91.1$ min/day, Băieși Roma $207.55 \pm 172.1$ min/day, and non-Roma $234.12 \pm 167.3 \mathrm{~min} /$ day). Both Roma groups had significantly lower percentages of gardening and sport activities compared to non-Roma. Women had a higher level of daily physical activity than men in the Gabor Roma population (144.22 $\pm 109.4 \mathrm{~min} /$ day vs. $79.71 \pm 58.2 \mathrm{~min} /$ day, $p=0.001)$. In the two other groups the differences were not statistically significant. Conclusions: Both Roma groups had significantly lower levels of daily physical activity, with differences between genders. Both Roma groups were lesser engaged in sports and gardening than nonRoma subjects.
\end{abstract}

Keywords: Gabor Roma, Băieși Roma, physical activity level

\section{INTRODUCTION}

Roma ethnicity represents $3.29 \%$ of Romania's population, but it is assumed that the real percentage is higher. ${ }^{1}$ The Roma population experienced a fundamental change in their way of life in the last few years. On the other hand, originating from the northern part of India, they are still a group with distinct genetic and socio-cultural features, which has on impact on their phenotype. ${ }^{2}$ Traditionally, they do not own land, and, even in rural settings, their income is mainly from trading, not farming. The evaluation of the metabolic status and lifestyle habits 
of the Roma started a decade ago, showing higher degrees of obesity, metabolic syndrome, and cardiovascular risk profile; however, data were conflicting. ${ }^{3-7}$ Studies existing so far did not take into account the heterogeneity of this ethnic group, with subgroups having different languages, traditions, income, and beliefs; consequently, the evaluation of these groups needs to be done distinctly. It is well established that the level of physical activity is one of the key risk factors in cardiovascular disease. ${ }^{8,9}$ Physical activity patterns may differ among different ethnic groups, as it was demonstrated in several studies. ${ }^{10}$ There were no specific epidemiological studies conducted among the Roma regarding their lifestyle and level of physical activity. Our aim was to evaluate the levels and patterns of physical activity of two different Roma populations compared to non-Roma.

\section{MATERIAL AND METHODS}

We present preliminary data on physical activity-related findings of an ongoing larger non-interventional, population-based, cross-sectional survey, evaluating lifestyle, socio-cultural status, metabolic syndrome, and genetic traits among two Roma subgroups.

The study population consisted of Gabor Roma, Băieși Roma, and non-Roma subjects living in a rural environment in Mureș County, Romania. The community was approached through the general practitioner and community leaders. Screening took place at the general practitioner's office and facilities at the local church. Previously trained medical staff was involved in assisting participants to answer the questionnaires and helped to complete measurements.

In total, 231 Gabor Roma, 111 Băieși Roma, and 183 non-Roma were included. The Gabor Roma is a gipsy subgroup living mainly in Transylvania, having an archaic and strong community structure. They are relatively prosperous, affiliated to a neo-protestant church. The Băieși Roma are on average poor, less well organized, not keeping traditions. We involved non-Roma participants from the same area. The groups were age and sex matched. We included all subjects older than 18 years who were residing in the area and were willing to sign the informed consent.

A lifestyle and social life-related questionnaire was administered, which also included the short form of the International Physical Activity Questionnaire. ${ }^{11}$ We evaluated daily physical activity in the last 7 days (min/day), considering minutes of moderate-intensity activity and physical activity categories in which they mainly took part such as walking, gardening, household activity, and sports.

Anthropometric parameters: weight, height, waist and hip circumferences (WC and HC) were measured with a standard clinical scale and a centimeter according to standard procedures. Body mass index (BMI) and waist-hip ratio (WHR) were calculated (weight/height ${ }^{2}$ and waist circumference/hip circumference, respectively). The presence of obesity was defined as a BMI $\geq 30 \mathrm{~kg} / \mathrm{m}^{2}$.

The study was approved by the Ethics Committee of the University of Medicine, Pharmacy, Sciences and Technology of Târgu Mureș, Romania.

\section{Statistical analysis}

The results of the three groups were compared using oneway ANOVA test for scale variables and the Chi square test for categorical variables. Student's t-test was used to compare gender differences. Correlations within groups were tested with linear logistic regression, and distribution was tested with the Kolmogorov Smirnov test. Statistical analysis was performed using SPSS version 18 (SPSS Inc., Chicago, USA), and a p value of $<0.05$ was considered to be statistically significant.

\section{RESULTS}

The study population consisted of Gabor Roma ( $\mathrm{n}=231$, mean age $41.74 \pm 14.03$ years, $45.8 \%$ men), Băieși Roma ( $\mathrm{n}=111$, mean age $40.30 \pm 14.0$ years, $40.5 \%$ men), and non-Roma $(n=183$, mean age $=44.62 \pm 14.6$ years; $41.5 \%$ men) participants. Demographic and health-related characteristics of the study population are presented in Table 1.

In our study population, Gabor Roma had a significantly higher BMI, WC, and prevalence of obesity compared to Băieși Roma or non-Roma, with Băieși Roma having the lowest values. Gabor Roma had a significantly higher percentage of obesity compared to Băieși Roma and nonRoma, and there was no difference between the other two groups (Table 1).

The lowest level of daily activity was registered in the Gabor Roma group (118.6 $\pm 91.1 \mathrm{~min} /$ day), followed by the Băieși Roma (207.55 $\pm 170.3 \mathrm{~min} /$ day) and the nonRoma subjects $(243.12 \pm 167.3 \mathrm{~min} /$ day $)$, the difference being statistically significant $(\mathrm{p}=0.00)$. Using a linear regression model, BMI and WC being the dependent variables, we found a strong correlation between daily activity and BMI $(\mathrm{F}=4.25, \mathrm{p}=0.04)$ in the Gabor Roma group.

Both Roma groups had significantly lower percentages of gardening and sport activities compared to non-Roma, but there was no difference between them (Figure 1).

Men had a higher level of daily physical activity than women in the Gabor Roma population (144.22 \pm 109.4 $\mathrm{min} /$ day vs. $79.71 \pm 58.2 \mathrm{~min} /$ day, $\mathrm{p}<0.001)$. In the other 
TABLE 1. Demographic and health-related characteristics of the three ethnic groups

\begin{tabular}{lcccc}
\hline & Gabor Roma & Băieși Roma & Non-Roma & p value *\# \\
\hline N & 231 & 111 & 183 & \\
Age (years) & $41.74 \pm 14.0$ & $40.30 \pm 14.0$ & $44.62 \pm 14.6$ & $0.861^{*}, 0.122^{\#}$ \\
Gender (n/\% men) & $106 / 45.8$ & $45 / 40.5$ & $76 / 41.5$ & $0.127^{*}, 0.451^{\#}$ \\
BMl (kg/m²) & $31.1 \pm 4.6$ & $27.4 \pm 5.2$ & $28.66 \pm 5.7$ & $0.004^{*}, 0.021^{\#}$ \\
Obesity (n/\%) & $157 / 68$ & $47 / 42.3$ & $79 / 43.1$ & $0.013^{*}, 0.028^{\#}$ \\
WC (cm) & $102.73 \pm 13.35$ & $89.54 \pm 13.83$ & $98.21 \pm 13.8$ & $0.003^{*}, 0.041^{\#}$ \\
WHR & $0.91 \pm 0.1$ & $0.83 \pm 0.0$ & $0.91 \pm 0.0$ & $0.035^{*}, 0.896^{\#}$ \\
Daily moderate physical activity (min/day) & $118.6 \pm 91.1$ & $207.55 \pm 172.1$ & $234.12 \pm 167.3$ & $0.001^{*}, 0.000^{\#}$ \\
Practicing sports (N/\%) & $6 / 2.6$ & 0 & $23 / 12.5$ & $0.041^{*}, 0.004^{\#}$ \\
Walking (N/\%) & $93 / 40.2$ & $40 / 36.0$ & $53 / 28.9$ & $0.392^{*}, 0.044^{\#}$ \\
Gardening (N/\%) & $54 / 23.3$ & $30 / 27.0$ & $130 / 71.0$ & $0.284^{*}, 0.000^{\#}$ \\
Household activity (N/\%) & $143 / 61.9$ & $60 / 54.0$ & $126 / 68.8$ & $0.186^{*}, 0.532^{\#}$ \\
\hline
\end{tabular}

* between Gabor Roma and Băieși Roma; \# between Gabor Roma and non-Roma. Continual values mean \pm SD

groups the differences between genders were not statistically significant: in the Băieși Roma $211.52 \pm 171.1 \mathrm{~min} /$ day for women vs. $195.3 \pm 186.0 \mathrm{~min} /$ day for men $(\mathrm{p}=0.79)$, and in the non-Roma $229.4 \pm 121.3 \mathrm{~min} /$ day for women vs. $253.6 \pm 117.6 \mathrm{~min} /$ day for men (Figure 2).

\section{DISCUSSIONS}

This study evaluated physical activity patterns in two Roma subgroups and a non-Roma group. The entire cohort had a relatively high average daily level of moderate physical activity (Gabor Roma $118.6 \pm 91.1 \mathrm{~min} /$ day, Băieși Roma $207.55 \pm 172.1 \mathrm{~min} /$ day, and non-Roma $234.12 \pm 167.3 \mathrm{~min} /$ day), probably due to their lifestyle in the rural environment where they all came from. However, both Roma subgroups had a lower level of physical activity compared to non-Roma, with no significant differences between the two Roma groups, despite their different socioeconomic status and lifestyle. The results are consistent with other findings, ${ }^{12,13}$ and might be explained by the fact that Roma are not tied to land and generally do not own agricultural areas larger than their garden. Gabor Roma men are involved mostly in trade, and Băieși Roma frequently are unemployed, thus less engaged in work-related physical activities.

Gabor Roma were significantly more obese than Băieși Roma and non-Roma. The level of physical activity was strongly correlated with the BMI, mainly in the Gabor Roma group. The relationship between obesity and physical activity is well documented in many different age, gender, and ethnic groups. ${ }^{14}$

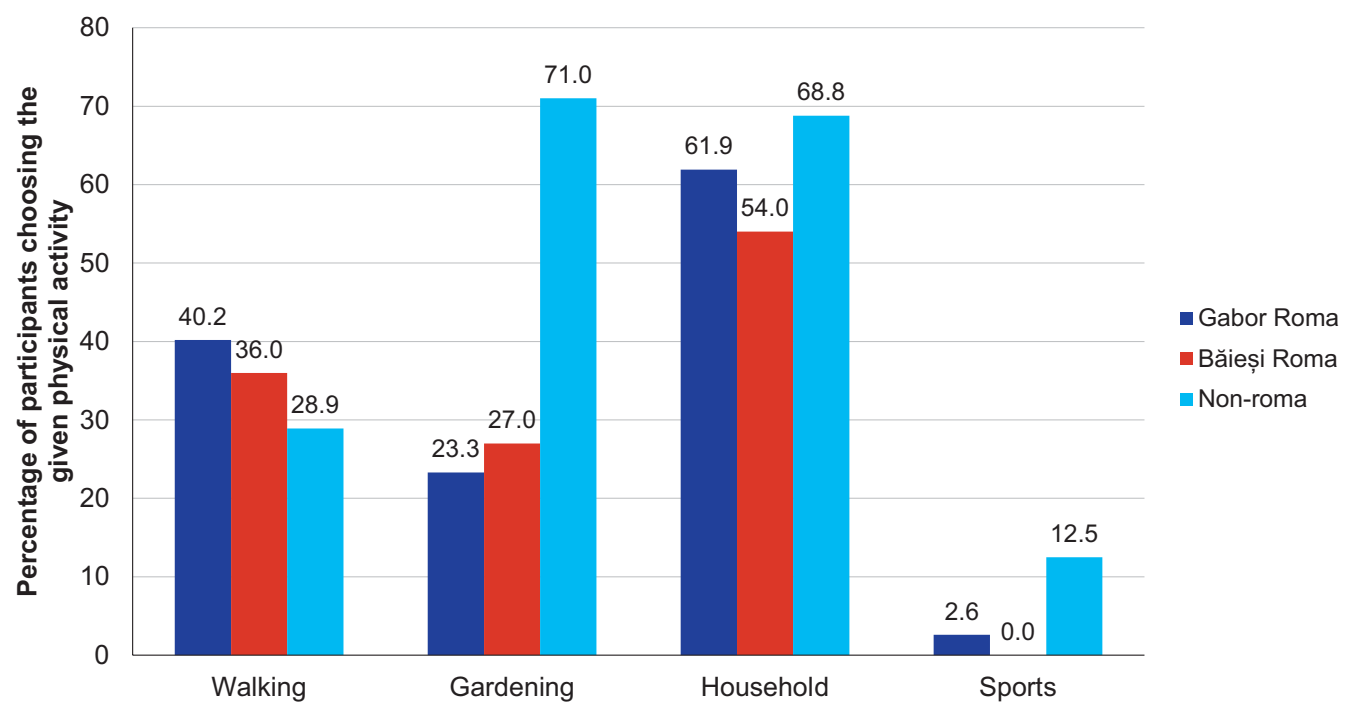

FIGURE 1. Percentage of the three ethnic groups choosing specific types of physical activity 


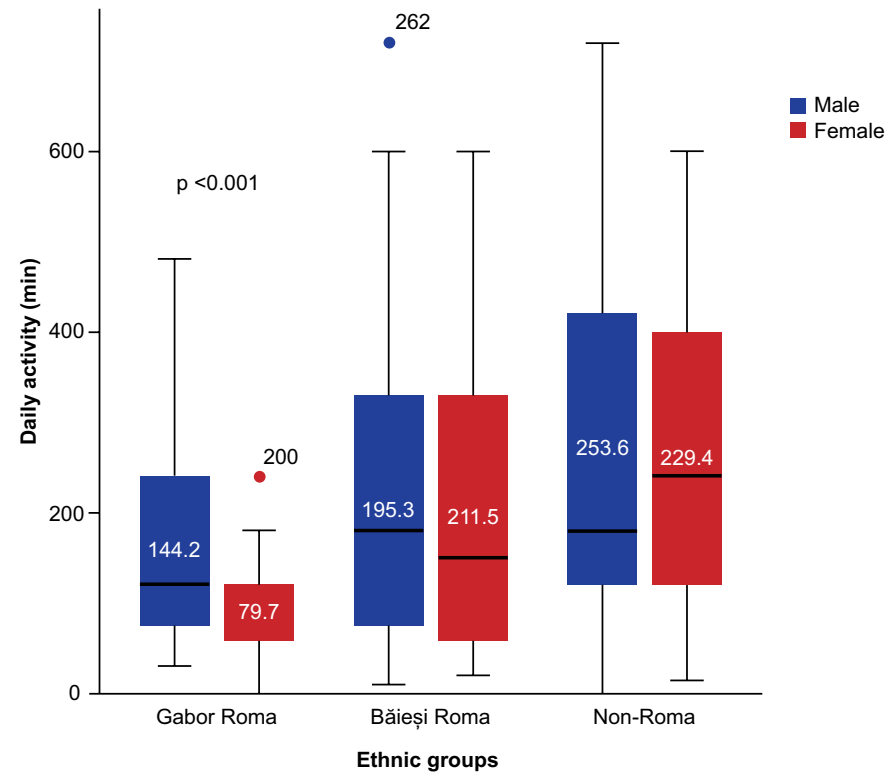

FIGURE 2. Daily activity among men and women in the three ethnic groups

As it was presented in the Roma Health Report of the European Union, ${ }^{15}$ the gipsy population has an unhealthy lifestyle overall. They are less engaged in physical activities with higher intensity such as sports or gardening, their main exercise being walking and everyday work in and around the house.

Women had a very distinct physical activity pattern in both Roma subgroups compared to the non-Roma. ${ }^{16} \mathrm{Ga}$ bor Roma women had a higher level of physical activity, albeit they were walking less than men, explained by the fact that they are mostly at home, almost none of them being engaged in any sport. Gender differences were widely observed in Roma studies. In our study, differences in BMI and physical activity patterns were more obvious in the Gabor Roma population, which has a very archaic family model.

Our investigation included a relatively small number of participants so far, but the local Roma population is very hostile towards any screening action, considering it an aggression upon their community and not wanting to have diseases diagnosed, disease being a shame in their culture. The strength of our investigation is the fact that it compares the physical activity patterns of two different Roma subgroups.

\section{CONCLUSIONS}

Both Roma groups had significantly lower levels of daily physical activity, differences between genders being more obvious in the Gabor Roma group, where men were less active. Both Roma groups were lesser engaged in sports and gardening than non-Roma.

\section{ACKNOWLEDGEMENT}

Funding: This work was supported by SC Cosamext through the University of Medicine, Pharmacy, Sciences and Technology of Târgu Mureș, Romania [grant number 13429, 2016].

\section{CONFLICT OF INTEREST}

We have no conflict of interests to declare.

\section{REFERENCES}

1. Institutul Național de Statistică. Recensământul populației și a locuințelor 2011. http://www.recensamantromania.ro/noutati/volumul-ii-populatiastabila-rezidenta-structura-etnica-si-confesionala (7 January 2019)

2. Mendizabal I, Lao O, Marigorta $U$, et al. Reconstructing the Population History of European Romani from Genome-wide Data. Curr Biol. 2012;22:2342-2349.

3. Weiss E, Japie C, Balahura A, Bartos D, Badila E. Cardiovascular risk factors in a Roma sample population from Romania. Rom J of Intern Med. 2018;56:193-202

4. Kosa Zs, Moravtsik Kornitzky A, Dioszegi J, et al. Prevalence of metabolic syndrome among Roma: a comparative health examination survey in Hungary. Eur J of Public Health. 2015;25:299-304.

5. de Courten B, de Courten M, Hanson R, et al. Higher prevalence of type 2 diabetes, metabolic syndrome and cardiovascular diseases in gypsies than in non-gypsies in Slovakia. Diabetes Res and Clin Pract. 2003;62:95103.

6. Enache G, Rusu E, llinca A, Rusu F, Costache A, Radulian G. Prevalance of obesity and newly diagnosed diabetes in the roma population from a county in the south part of Romania (Călărași county) - preliminary results. Rom J Diabetes Nutr Metab Dis. 2016;23:027-036.

7. Enache G, Rusu E, llinca A, et al. Prevalence of overweight and obesity in a Roma population from Southern Romania - Calarasi County. Acta Endo. 2008;14:122-130.

8. Agarwal SK. Cardiovascular benefits of exercise. Int J Gen Med. 2012;5:541-545.

9. Warburton DER, Nicol CW, Bredin SSD. Health benefits of physical activity: the evidence. CMAJ. 2006;174:801-9.

10. He XZ, Baker DW. Differences in leisure-time, household, and workrelated physical activity by race, ethnicity, and education. J Gen Intern Med. 2005;20:259-66.

11. Ainsworth BE, Bassett DR Jr, Strath SJ, et al. Comparison of three methods for measuring the time spent in physical activity. Med Sci Sports Exerc. 2000;32:457-64

12. Babinská I, Gecková AM, Jarcuska P, et al. Does the population living in Roma settlements differ in physical activity, smoking and alcohol consumption from the majority population in Slovakia. Cent Eur J Public Health. 2014;22:22-27.

13. Beenackers MA, Kamphuis CBM, Giskes K, et al. Socioeconomic inequalities in occupational, leisure-time, and transport related physical activity among European adults: a systematic review. Int J Behav Nutr Phys Act. 2012;19:116-119.

14. Nelson CC, Wagner GR, Caban-Martinez AJ, et al. Physical Activity and Body Mass Index: The Contribution of Age and Workplace Characteristics. Am J Prev Med. 2014;46:42-51.

15. Roma Health Report. Health status of the Roma population Data collection in the Member States of the European Union, 2014. https://ec.europa.eu/ health//sites/health/files/social_determinants/docs/2014_roma_health_ report_es_en.pdf (7 January 2019)

16. Coe K, Čvorović J. The health of Romanian Gypsy women in Serbia. Health Care Women Int. 2017;38:409-422. 